\title{
Interpretacja art. 45 ust. 1 ustawy z 26 stycznia 2018 r. o Straży Marszałkowskiej (w zakresie pojęcia "zajęcia zarobkowe") ${ }^{1}$
}

\begin{abstract}
Interpretation of Article 45 para. 1 of the Act of $26^{\text {th }}$ January 2018 on the Parliament's Guard (in terms of "gainful activity"): The statutory prohibition on taking up paid employment is the most rigorous one among analogous restrictions on regarding functionaries of other uniformed services. This regulation prohibits officers of the Parliament's Guard from undertaking other gaining activities than the ones of scientific or scientificdidactic nature, to which the Chief of the Chancellery of the Sejm consents on condition that it does not interfere with the performance of official tasks. The Parliamentary Guardian also cannot run his own economic activity.
\end{abstract}

Keywords: economic activity, lease, Parliament Guard

Słowa kluczowe: działalność gospodarcza, najem, Straż Marszałkowska

Ekspert ds. legislacji BAS - irena.galinska-raczy@sejm.gov.pl • https://orcid.org/0000-0003-3586-0126

\section{Przedmiot opinii}

Przedmiotem opinii jest następujące zagadnienie: „jakie formy działalności obejmuje pojęcie »zajęcia zarobkowego«, którym posłużono się w art. 45 ust. 1 ustawy o Straży Marszałkowskiej z 26 stycznia 2018 r., czy pojęcie to ogranicza się do świadczenia usług na podstawie umów cywilnoprawnych (dzieło, zlecenie itp.) oraz wykonywania działalności gospodarczej w rozumieniu przepisów ustawy - Prawo przedsiębiorców z 6 marca 2018 r., czy też obejmuje np. uzyskiwanie korzyści z posiadanego majątku w postaci najmu okazjonalnego mieszkania?".

1 Opinia prawna w sprawie interpretacji art. 45 ust. 1 ustawy $z$ dnia 26 stycznia 2018 r. o Straży Marszałkowskiej (w zakresie pojęcia „zajęcia zarobkowe”) sporządzona 13 listopada 2018 r. na zlecenie Klubu Parlamentarnego Prawo i Sprawiedliwość; BAS-WAP 2393/18. 
Opinia została sporządzona $\mathrm{z}$ uwzględnieniem m.in. następujących aktów prawnych:

- ustawa z 26 stycznia 2018 r. o Straży Marszałkowskiej, Dz.U. poz. 729; dalej: ustawa o SM,

- ustawa z 21 sierpnia 1997 r. o ograniczeniu prowadzenia działalności gospodarczej przez osoby pełniące funkcje publiczne, t.j. Dz.U. 2017, poz. 1393; dalej: ustawa antykorupcyjna,

- ustawa z 26 czerwca 1974 r. - Kodeks pracy, t.j. Dz.U. 2018, poz. 917 i 1000,

- ustawa z 21 listopada 2008 r. o służbie cywilnej, t.j. Dz.U. 2018, poz. 1559; dalej: ustawa o służbie cywilnej,

- ustawa z 6 kwietnia 1990 r. o Policji, t.j. Dz.U 2017, poz. 2067, ze zm.; dalej: ustawa o Policji,

- ustawa z 16 listopada 2016 r. o Krajowej Administracji Skarbowej, t.j. Dz.U. 2018, poz. 508, ze zm.; dalej: ustawa o KAS,

- ustawa z 16 marca 2001 r. o Biurze Ochrony Rządu, Dz.U. 2017, poz. 985, ze zm.

\section{Pojęcie „inne zajęcia zarobkowe” w rozumieniu art. 45 ust. 1 ustawy o Straży Marszałkowskiej}

1. Zgodnie z art. 45 ust. 1 ustawy o SM funkcjonariuszowi Straży Marszałkowskiej nie wolno: pozostawać w stosunku pracy oraz podejmować innego zajęcia zarobkowego poza służbą.

Artykuł 45 ust. 1 ustala dwa zakazy: odnoszący się do zatrudnienia w charakterze pracownika (czyli zgodnie z art. 2 Kodeksu pracy ${ }^{2}$ zatrudnienia na podstawie umowy o pracę, powołania, wyboru, mianowania i spółdzielczej umowy o pracę) oraz do zatrudnienia w ramach pozapracowniczych stosunków zatrudnieniowych, takich jak np. umowy cywilnoprawne (typu umowa-zlecenia, umowa agencyjna czy umowa o dzieło), ale również np. do pozostawania w stosunkach służbowych (np. w innych służbach zmilitaryzowanych).

Sformułowanie tych zakazów różni się od zakazów ustalonych dla innych formacji zmilitaryzowanych, bowiem np. zgodnie z art. 62 ust. 1 ustawy o Policji policjant nie może podejmować zajęcia zarobkowego poza służbą bez pisemnej zgody przełożonego ani wykonywać czynności lub zajęć sprzecznych z obowiązkami wynikającymi z ustawy lub podważających zaufanie do Policji. W komentarzu do tego przepisu stwierdzono, że: [t]ermin „zajęcie zarobkowe” obejmuje wszelkie formy zatrudnienia połączone z uzyskiwaniem dochodów czyli działalność gospodarcza, stosunek pracy, stosunek służbowy oraz każdy rodzaj umowy cy-

2 Art. 2. Pracownikiem jest osoba zatrudniona na podstawie umowy o prace, powołania, wyboru, mianowania lub spółdzielczej umowy o pracę. 
wilnoprawnej. Nadto należy też uwzględnić członkostwo w organach statutowych jakichkolwiek instytucji jeżeli jest to połączone $z$ uzyskiwaniem dochodów pieniężnych stałych bądź okresowych. Zajęciem zarobkowym będzie też świadczenie pracy za wynagrodzeniem bez podpisania umowy, która precyzowałaby warunki wykonywanej działalności. [...] Policjant może więc podejmować w czasie wolnym od zajęć służbowych bez pisemnej zgody zajęcie, które nie jest zajęciem zarobkowym, $n p$. wykonywanie pracy społecznie użytecznej. $W$ doktrynie wyróżnia się także pojęcie zajęcia zarobkowego oraz dodatkowego zatrudnienia. Przyjmuje się, że dodatkowe zatrudnienie to pozostawanie w stosunku pracy, natomiast zajęcie zarobkowe to wszelkie formy zarobkowania na podstawie umów cywilnoprawnych. Każde dodatkowe zatrudnienie jest zajęciem zarobkowym, nie każde już zajęcie zarobkowe jest zarazem dodatkowym zatrudnieniem $[\ldots]^{3}$.

Bogusław Cudowski w monografii Dodatkowe zatrudnienie $e^{4}$ stwierdził, że art. 62 ust. 1 ustawy o Policji ma identyczny zakres przedmiotowy jak art. 67 ustawy z 12 października 1990 r. o Straży Granicznej, art. 63 ustawy z 26 kwietnia 1996 r. o Służbie Więziennej, art. 37 ust. 1 ustawy z 24 lipca 1999 r. o Służbie Celnej, art. 57a ustawy z 24 sierpnia 1991 r. o Państwowej Straży Pożarnej, art. 56 ustawy z 16 marca 2001 r. o Biurze Ochrony Rządu, art. 80 ustawy z 24 maja 2002 r. o Agencji Bezpieczeństwa Wewnętrznego oraz Agencji Wywiadu oraz art. 34 ust. 2 ustawy z 6 czerwca 1997 r. o Inspekcji Celnej. Stwierdzenie to wymaga aktualizacji z uwagi na zmianę stanu prawnego (przede wszystkim z uwagi na uchylenie ustawy o Biurze Ochrony Rządu i ustawy o Służbie Celnej).

W opinii B. Cudowskiego: Przedmiotem obowiązku uzyskania zgody sa zajęcia zarobkowe poza stużba. Pierwszym elementem zakresu przedmiotowego zakazu sq "zajęcia zarobkowe". Co do zasady chodzi tu więc o wszelkie zajęcia zarobkowe, niezależnie od ich podstawy prawnej. W szczególności będa to więc zatrudnienia pracownicze i cywilnoprawne, a więc zajęcia wykonywane w stosunkowo długim czasie. W zakresie przedmiotowym mieszczq się również inne stosunki stużbowe, choć praktycznie nie byłoby możliwe podjęcie takiego dodatkowego zatrudnienia. $Z$ pewnościa obowiąek uzyskania zgody dotyczy również prowadzenia działalności gospodarczej. $j^{5}$ Autor ten zwraca uwagę, że regulacja ograniczeń w zakresie prowadzenia działalności gospodarczej funkcjonariuszy wykazuje istotne różnice (niektóre z pragmatyk regulują problem prowadzenia działalności gospodarczej, np. ustawa o Służbie Celnej, a inne, np. ustawa o funkcjonariuszach ABW i AW, odsyła w tej kwestii do ustawy antykorupcyjnej).

Zdaniem B. Cudowskiego problemem jest to, że przepisy omawianych pragmatyk nie dają żadnych wskazówek co do czasu trwania zajęcia zarobkowego. Można więc twierdzić, że chodzi o wszelkie, nawet jednorazowe i wykonywane bez

3 B. Opaliński, M. Rogalski, P. Szustakiewicz, Ustawa o Policji. Komentarz, 2015, Legalis.

4 2007, LEX.

5 Ibidem. 
podstawy prawnej zajęcia zarobkowe, jak np. sprzedaż choinek. Jednak ze względu na zasadę wolności pracy nie należy, moim zdaniem, stosować tu wykładni literalnej. Jednorazowe zajęcia, zarówno zarobkowe, jak i nieodpłatne, powinny być zakazane, jeżeli naruszaja jednocześnie obowiązki funkcjonariusza. Poza zakresem przedmiotowym tych przepisów powinny zatem pozostać także czynności, które zwiazane sa z prowadzeniem normalnych spraw życiowych oraz jednorazowych czynności podlegających prawu autorskiemú.

To ostanie stwierdzenie nie będzie miało zastosowania do strażników SM z uwagi na art. 46 ustawy o SM, który stanowi, że Szef Kancelarii Sejmu może zezwolić funkcjonariuszowi Straży Marszałkowskiej na wykonywanie zajęcia zarobkowego poza służbą o charakterze naukowym lub naukowo-dydaktycznym, jeżeli nie koliduje to z wykonywaniem przez niego zadań służbowych. Przepis ten $\mathrm{w}$ zestawieniu $\mathrm{z}$ art. 45 ustawy o SM (który zakazuje podejmowania jakichkolwiek zajęć zarobkowych poza służbą w SM) oznacza, że strażnicy SM nie mogą podejmować żadnych innych zajęć zarobkowych poza tymi wskazanymi w art. 46. Innymi słowy, ustawa o SM dopuszcza na zasadzie wyjątku od generalnego zakazu podejmowania przez strażników SM zajęć zarobkowych poza służbą możliwość wykonywania zajęć naukowych lub naukowo-dydaktycznych (pod warunkiem uzyskania zgody Szefa Kancelarii Sejmu).

2. Omawiane unormowania ustawy o SM są zatem unormowaniami najbardziej rygorystycznymi wśród ograniczeń obowiązujących funkcjonariuszy służb mundurowych. Artykuły 45 i 46 ustawy o SM są porównywalne z art. 34 ust. 2 nieobowiązującej ustawy z 6 czerwca 1997 r. o Inspekcji Celnej (Dz.U. nr 71, poz. 449, ze zm.), zgodnie z którym funkcjonariusze tej służby mogli wykonywać dodatkowe zajęcia zarobkowe jedynie na zlecenie organów administracji państwowej za zgodą Generalnego Inspektora Celnego lub w zakresie działalności publicystycznej i dydaktycznej.

Artykuły 45 i 46 ustawy o SM można również porównywać z art. 205 ustawy o $\mathrm{KAS}^{7}, \mathrm{z}$ którego wynika, że funkcjonariusze KAS mogą wykonywać różnego rodzaju zajęcia zarobkowe pod warunkiem uzyskania zgody, a na niektóre z tych zajęć $c^{8}$ nie muszą nawet uzyskiwać takiej zgody - wystarczy, że powiadomią kie-

\section{$6 \quad$ Ibidem.}

7 Art. 205. 1. Funkcjonariusz może wykonywać dodatkowe zajęcia zarobkowe jedynie za zgoda kierownika jednostki organizacyjnej. W odniesieniu do dyrektora izby administracji skarbowej lub jego zastępcy zgody udziela Szef Krajowej Administracji Skarbowej. 2. Minister właściwy do spraw finansów publicznych określi, $w$ drodze zarządzenia, rodzaje zajęć zarobkowych, które nie wymagaja zgody kierownika jednostki organizacyjnej. 3. W przypadkach, o których mowa w ust. 2, funkcjonariusz jest obowiązany poinformować kierownika jednostki organizacyjnej przed podjęciem tego zajęcia.

8 Te, które zostały wskazane w zarządzeniu Ministra Finansów z 26 lutego 2018 r. w sprawie dodatkowych zajęć zarobkowych wykonywanych przez funkcjonariuszy Służby Celno-Skarbowej (Dz.Urz. MF 2018, poz. 15). W myśl $\$ 1$ tego aktu: 
rownika jednostki organizacyjnej o zamiarze ich podjęcia. Z porównania treści omawianych przepisów ustawy o SM oraz ustawy o KAS można stwierdzić, że funkcjonariusze SM nie mogą np. prowadzić działalności publicystycznej (a jednocześnie Szefowi Kancelarii Sejmu nie przyznano uprawnienia, by wyrażał zgodę na wykonywanie przez strażnika SM tego rodzaju działalności).

3. Artykuł 45 ust. 1 ustawy o SM mówi o „pozostawaniu w stosunku pracy” i „podejmowaniu innych zajęć zarobkowych [innych niż stosunek pracy] poza służbą".

Podobne rozróżnienie znajdujemy np. w art. 80 ust. 1 i 2 ustawy o służbie cywilnej ${ }^{9}$. L. Bielecki, komentując te przepisy, stwierdza: Termin „dodatkowe zatrudnienie" nie jest zdefiniowany przez ustawe [z 2008 r.] o stużbie cywilnej. Wydaje się, że powinien być rozumiany jako zatrudnienie wyłacznie na podstawie stosunku pracy, a zajęcia zarobkowe powinny być rozumiane jako wszelkie inne formy zarobkowania, na przykład umowa o dzieło, zlecenia, agencyjna lub o prace nakładczą $q^{10}$.

Należy przyjąć, że przez „inne zajęcia zarobkowe” można rozumieć wszelkie formy aktywności inne niż stałe spełnianie świadczeń na rzecz podmiotu

1. Zarzadzenie określa rodzaje zajęć zarobkowych, wykonywanych przez funkcjonariuszy Stużby Celno-Skarbowej, które nie wymagają zgody kierownika jednostki organizacyjnej.

2. Do zajęć, o których mowa w ust. 1, należą:

1) działalność naukowa niezwiązana z zakresem działania Krajowej Administracji Skarbowej;

2) działalność publicystyczna niezwiązana z zakresem działania Krajowej Administracji Skarbowej;

3) działalność dydaktyczna niezwiązana $z$ zakresem działania Krajowej Administracji Skarbowej, w zakresie nauczania $w$ szkołach oraz na kursach organizowanych przez urzędy publiczne;

4) działalność dydaktyczna wykonywana na zlecenie jednostek organizacyjnych Krajowej Administracji Skarbowej;

5) udział w komisjach egzaminacyjnych powolywanych przez jednostki organizacyjne Krajowej Administracji Skarbowej;

6) wykonywanie zawodu tłumacza przysięgłego;

7) wykonywanie czynności biegłego sądowego.

9 1. Członek korpusu służby cywilnej nie może podejmować dodatkowego zatrudnienia bez pisemnej zgody dyrektora generalnego urzędu ani wykonywać czynności lub zajęć sprzecznych $z$ obowiązkami wynikającymi z ustawy lub podważających zaufanie do służby cywilnej.

2. Urzędnik służby cywilnej nie może podejmować zajęć zarobkowych bez pisemnej zgody dyrektora generalnego urzędu.

10 L. Bielecki, Ustawa o służbie cywilnej. Kontrowersje natury prawnej dotyczace pracobiorcy jako źródła rozwiązań prawnych (zagadnienia wybrane), „Przegląd Prawa Publicznego" 2014, nr 7-8. 
zatrudniającego w ramach rozłożonej w czasie relacji. Mogą to zatem być formy odpłatnej aktywności zarówno periodycznej, jak i jednorazowej. Omawiane pojęcie obejmuje zajęcia i sposoby zarobkowania bez względu na ich częstotliwość.

Odniesieniem do przykładów zajęć zarobkowych, o których mowa w art. 45 ust. 1 ustawy o SM, mogą być stanowiska prezentowane w orzecznictwie sądowym, odnoszące się do funkcjonariuszy innych służb zmilitaryzowanych. Wskażmy następujące rozstrzygnięcia:

- wyrok Wojewódzkiego Sądu Administracyjnego w Poznaniu z 8 października 2015 r., sygn. akt IV SA/Po 467/15 ${ }^{11}$,

- wyrok Wojewódzkiego Sądu Administracyjnego w Gliwicach z 28 października 2013 r., sygn. akt IV SA/Gl 1104/12 ${ }^{12}$,

11 LEX nr 1933084: 1. Za zajęcie zarobkowe uznane powinno być każde zajęcie, które wiąże się z uzyskaniem wynagrodzenia, zapłaty lub też innych korzyści majątkowych. Termin „zajęcie zarobkowe” powinien być rozumiany szeroko i obejmuje wszelkie formy zatrudnienia połączone z uzyskiwaniem dochodów czyli działalność gospodarcza, stosunek pracy, stosunek stużbowy oraz każdy rodzaj umowy cywilnoprawnej.

2. O ile uzasadnione jest stanowisko, że dokonując wykładni przepisu art. 62 ust. 1 ustawy z 1990 r. o Policji za zajęcie zarobkowe nie można uznać zajęcia, za które przysługiwałyby jedynie ryczałt za zwrot wydatków, to jednak nie jest już zasadne stanowisko, iż sprawowanie funkcji kuratora społecznego nie może zostać uznane za zajęcie zarobkowe w myśl ww. przepisu. Kurator taki, poza ryczałtem za zwrot wydatków otrzymuje również ryczalt, o którym mowa $w$ art. 91 ust. 1 ustawy $z 2001$ r. o kuratorach sadowych i ryczałt ten musi zostać uznany za wynagrodzenie. Tak więc prawidłowym jest stanowisko, że wykonywanie funkcji kuratora społecznego, jest zajęciem zarobkowym, o którym mowa w art. 62 ust. 1 ustawy o Policji.

Pojęcie zajęcia zarobkowego, o którym mowa $w$ art. 62 ust. 1 ustawy o Policji, nie posiada swojej definicji legalnej na gruncie ustawy o Policji. Określenie znaczenia tego pojęcia powinno się więc w pierwszym rzędzie opierać na gruncie wykładni językowej. Za zajęcie zarobkowe uznane powinno być więc każde zajęcie, które wiąże się z uzyskaniem wynagrodzenia, zapłaty lub też innych korzyści majątkowych. Termin „zajęcie zarobkowe" powinien być rozumiany szeroko i obejmuje wszelkie formy zatrudnienia połaczone z uzyskiwaniem dochodów czyli działalność gospodarczą, stosunek pracy, stosunek stużbowy oraz każdy rodzaj umowy cywilnoprawnej. Nadto należy tė் uwzględnić członkostwo w organach statutowych jakichkolwiek instytucji jeżeli jest to połaczone $z$ uzyskiwaniem dochodów pieniężnych stałych bądź okresowych. Zajęciem zarobkowym będzie też świadczenie pracy za wynagrodzeniem bez podpisania umowy, która precyzowałaby warunki wykonywanej działalności (por. B. Opaliński, M. Rogalski, P. Szustakiewicz, Ustawa o Policji. Komentarz, wyd. C.H.BECK, Warszawa 2015, s. 255, wyrok WSA w Szczecinie z dnia 7 maja 2008 r., II SA/Sz 99/08 dostępny pod adresem internetowym http://cbois.nsa.gov.pl).

12 LEX nr 1663466: Pojęcie „zajęcie zarobkowe” obejmuje wszelkie formy zatrudnienia połaczone z uzyskiwaniem dochodów czyli działalność gospodarcza, stosunek pracy, stosunek stużbowy oraz każdy rodzaj umowy cywilnoprawnej. Oczywistym przy tym jest, $\dot{z}$ e należy też uwzględnić członkostwo w organach statutowych jakichkolwiek instytucji 
- wyrok Wojewódzkiego Sądu Administracyjnego w Szczecinie z 25 stycznia 2017 r., sygn. akt II SA/Sz 1395/16 ${ }^{13}$.

4. Do niektórych ze wskazanych wyżej wyroków odwołano się w odpowiedzi sekretarza stanu w Ministerstwie Spraw Wewnętrznych i Administracji na interpelację poselską nr 695/2016 (VIII kadencja) w sprawie podejmowania dodatkowego zatrudnienia przez policjantów ${ }^{14}$. W odpowiedzi tej stwierdzono m.in.: Zajęciem zarobkowym jest zatem każda forma działalności łącząca się z uzyskiwaniem dochodów, w tym działalność gospodarcza, stosunek stużbowy, stosunek pracy, umowa cywilnoprawna bądź inny stosunek prawny wynikający z określonych przepisów, niezależnie od tego, czy ma ona stały bądź niestały charakter, czy $w$ związku $z$ dana działalnością wynagrodzenie przysługuje z mocy ustawy lub na podstawie umowy oraz czy umowa taka została zawarta na piśmie, ustnie bądź per facta concludentia (tj. $w$ sposób dorozumiany). O zarobkowym charakterze zajęcia przesadza bowiem fakt wykonywania przez funkcjonariusza danej działalności lub danych czynności oraz należny z tego tytułu dochód (choćby nie został jeszcze wypłacony, pobrany itp.). Do zajęć zarobkowych, obok działalności gospodarczej, stosunku służbowego, stosunku pracy, umowy cywilnoprawnej bądź wynikającego z określonych przepisów innego stosunku prawnego należy także np. pełnienie funkcji biegłych sadowych, wydawanie odpłatnych opinii eksperckich $w$ ramach powołania na tzw. biegłych ad hoc oraz udział w polowaniach, jezeli udział w polowaniu lub upolowanie zwierzęcia wiąże się z określonym wynagrodzeniem.

Zajęciem zarobkowym nie jest natomiast zakładanie rachunków oszczędnościowo-rozliczeniowych, lokat oszczędnościowych oraz innych przewidujacych element

jeżeli jest to połaczone z uzyskiwaniem dochodów pieniężnych stałych bądź okresowych. Zajęciem zarobkowym będzie też świadczenie pracy za wynagrodzeniem bez podpisania umowy, która precyzowałaby warunki wykonywanej działalności.

13 Legalis nr 1602100: Zajęcie zarobkowe to zajęcie, za które przysługuje wynagrodzenie, a konieczność wypłaty wynagrodzenia może wynikać z przepisów, zawartej umowy lub ogólnie przyjętych zwyczajów. Niepodpisanie umowy, nieodebranie pieniędzy czy też ewentualne scedowanie odbioru zapłaty na inna osobę nie ma znaczenia przy ocenie czynu objętego postępowaniem dyscyplinarnym, opisanego w art. 62 ust. 1 ustawy z 6 kwietnia 1990 r. o Policji (t.j. Dz.U. z 2016 r. poz. 1782 ze zm.). Czynności te nie przesądzaja bowiem o tym, czy dane zajęcie było zajęciem zarobkowym. Inna interpretacja tego przepisu - przyjmująca, że tylko podpisanie umowy i pokwitowanie odbioru pieniędzy może być potraktowane jako uczestniczenie w wykonywaniu zajęcia zarobkowego - byłaby niczym nie uzasadnionym uprzywilejowaniem funkcjonariusza, który nie podpisat żadnych dokumentów, choć nie ulega wątpliwości, że wykonał czynności, za które należy się wynagrodzenie. Ponadto taka interpretacja art. 62 ust. 1 ustawy o Policji stanowitaby zachęte do obchodzenia prawa.

$14 \mathrm{Http} / /$ www.sejm.gov.pl/Sejm8.nsf/interpelacja.xsp?documentId=D2D30A882E5C8 ACCC1257F460050833B\&view=1. 
zysku instrumentów prawa bankowego. Także o ile dana osoba nie prowadzi w sposób zorganizowany i profesjonalny działalności polegajacej na obrocie udziałami lub akcjami spółek prawa handlowego, obligacjami, jednostkami funduszy inwestycyjnych oraz innymi podobnymi instrumentami prawa gospodarczego, trudno uznać działanie polegające na zakupie lub objęciu udziałów (np. w spółce z o.o.), akcji (zarówno w spółce akcyjnej, jak i spółce komandytowo-akcyjnej), obligacji lub innych instrumentów finansowych za zajęcie zarobkowe tej osoby. Stanowi ono bowiem formę oszczędzania lub inwestowania posiadanych środków pieniężnych. [...]

Różnorodność możliwych zajęć zarobkowych, jak również rozmaitość podmiotów, na rzecz których policjanci moga deklarować chęć świadczenia pracy, praktycznie uniemożliwia stworzenie katalogu czynności, zajęć $i$ zawodów na potrzeby udzielania zgody, o której mowa w art. 62 ust. 1 ustawy o Policji. Zauważyć należy, że zarówno kwalifikacja zawodów i specjalności wprowadzona rozporządzeniem Ministra Pracy i Polityki Społecznej z dnia 7 sierpnia 2014 r. w sprawie klasyfikacji zawodów i specjalności na potrzeby rynku pracy oraz jej stosowania (Dz.U. poz. 1145), jak i rozporządzenie Rady Ministrów z dnia 24 grudnia 2007 r. w sprawie Polskiej Klasyfikacji Działalności (PKD) (Dz.U. nr 251, poz. 1885 z późn. zm.) przewiduja kilka tysięcy możliwych zawodów, specjalności lub działalności, przy czym dokonanie jednoznacznej oceny, czy dany zawód, specjalność lub działalność umieszczone w przywołanych aktach koliduja z obowiązkami wynikającymi z ustaw lub podważaja zaufanie do Policji, nie jest możliwe w oderwaniu od okoliczności towarzyszacych $w$ indywidualnej sprawie.

Dodatkowo, w przypadku wielu rodzajów działalności np. działalności artystycznej, literackiej lub naukowej bądź innej podobnej nie jest możliwe ustalenie $z$ góry katalogu przypadków, w których wykonywanie przez policjanta takiej działalności jest równoznaczne $z$ wykonywaniem zajęcia zarobkowego $w$ rozumieniu art. 62 ust. 1 ustawy o Policji. Podobna sytuacja zachodzi w sytuacji uzyskiwania przez policjanta dochodów ze sprzedaży ruchomości oraz nieruchomości, co do których policjantowi przysługuje prawo własności lub współwłasności, gdyż $w$ takich przypadkach zarobkowy charakter danej działalności może zależeć od wielu czynników (np. od tego, czy taka działalność ma charakter stały, regularny, okazjonalny czy tylko jednorazowy, związany przykładowo z sytuacją życiową lub rodzinna policjanta).

5. Odnosząc powyższe rozważania do pytania na temat kwalifikowania najmu okazjonalnego mieszkania posiadanego przez funkcjonariusza Straży Marszałkowskiej jako zajęcia zarobkowego w rozumieniu art. 45 ust. 1 ustawy o SM, należy stwierdzić, że zakaz wynikający z tego przepisu może mieć zastosowanie tylko wtedy, gdy skala najmu będzie mogła być uznana jedynie za czerpanie pożytków z mienia, nie zaś jako prowadzenie działalności gospodarczej, która jest zakazana w uwagi na art. 45 ust. 2 ustawy o SM, zgodnie z którym: W stosunku do funkcjonariusza Straży Marszałkowskiej mają zastosowanie ograniczenia w prowadzeniu działalności gospodarczej wynikające z ustawy z dnia 21 sierpnia 
1997 r. o ograniczeniu prowadzenia działalności gospodarczej przez osoby petniące funkcje publiczne.

$\mathrm{Z}$ art. 45 ust. 1 ustawy o SM nie wynika wprost, że strażnik SM nie może prowadzić działalności gospodarczej (np. pozostawać w samozatrudnieniu). Przedmiotową kwestię jednoznacznie przesądza art. 4 pkt 6 ustawy antykorupcyjnej (w związku z art. 45 ust. 2 ustawy o SM), który zabrania prowadzenia działalności gospodarczej na własny rachunek (z wyjątkiem działalności wytwórczej w rolnictwie w zakresie produkcji roślinnej i zwierzęcej, w formie i zakresie gospodarstwa rodzinnego).

Artykuł 4 ustawy antykorupcyjnej stanowi, że osoby podlegające przepisom tej ustawy nie mogą:

- być członkami zarządów, rad nadzorczych lub komisji rewizyjnych spółek prawa handlowego,

- być zatrudnione lub wykonywać innych zajęć w spółkach prawa handlowego, które mogłyby wywołać podejrzenie o ich stronniczość lub interesowność,

- być członkami zarządów, rad nadzorczych lub komisji rewizyjnych spółdzielni, z wyjątkiem rad nadzorczych spółdzielni mieszkaniowych,

- być członkami zarządów fundacji prowadzących działalność gospodarczą,

- posiadać w spółkach prawa handlowego więcej niż 10\% akcji lub udziały przedstawiające więcej niż 10\% kapitału zakładowego - w każdej z tych spółek,

- prowadzić działalności gospodarczej na własny rachunek lub wspólnie z innymi osobami, a także zarządzać taką działalnością lub być przedstawicielem czy pełnomocnikiem $\mathrm{w}$ prowadzeniu takiej działalności; nie dotyczy to działalności wytwórczej w rolnictwie w zakresie produkcji roślinnej i zwierzęcej, w formie i zakresie gospodarstwa rodzinnego, a także pełnienia funkcji członka zarządu na podstawie umowy o świadczenie usług zarządzania, o której mowa w art. 5 ust. 1 pkt 1 ustawy z 9 czerwca 2016 r. o zasadach kształtowania wynagrodzeń osób kierujących niektórymi spółkami (Dz.U. poz. 1202 i 2260 ).

Należy zwrócić uwagę, że ze względu na art. 45 ust. 1 ustawy o SM niektóre zakazy wymienione w art. 4 ustawy antykorupcyjnej (takie, jak np. zakaz pozostawania członkiem zarządu fundacji, ale tylko w sytuacji, kiedy fundacja prowadzi działalność gospodarczą) nie mogą być stosowane wprost, ale powinny być stosowane $z$ uwzględnieniem zakazu sformułowanego jako zakaz podejmowania „innych zajęć zarobkowych” rozumianych możliwie szeroko.

Jacek Lipski w komentarzu do art. 56 ust. 1 ustawy o Biurze Ochrony Rządu ${ }^{15}$ stwierdził: Termin "zajęcie zarobkowe" nie zostało zdefiniowane $w$ ustawie, jak również $w$ innych aktach normatywnych, mimo że zasada reglamentowania podej-

15 Art. 56. 1. Funkcjonariusz nie może bez zezwolenia przełożonego podejmować dodatkowych zajęć zarobkowych poza służbą. 
mowania zajęć zarobkowych poza służbą znana jest również innym pragmatykom służbowym (zob. np. art. 62 ustawy o Policji, art. 67 ustawy o Straży Granicznej, art. 57a ustawy o Państwowej Straży Pożarnej, art. 80 ustawy o Agencji Bezpieczeństwa Wewnętrznego oraz Agencji Wywiadu). Wydaje się bliskie mniemaniu ustawodawcy traktowanie tego zwrotu w ujęciu słownikowym jako pracy zawodowej, zarobkowej (przynoszacej zysk, korzyść materialna), posady, fachu (W. Doroszewski (red.), „Słownik języka...”, t. X, s. 541 i 741). Zajęcie zarobkowe winno być rozumiane w kategorii profesji (nie jest nim np. wynajem lokalu, o ile nie prowadzi się działalności gospodarczej $w$ tym zakresie, czy też uzyskiwanie dochodów z posiadanych obligacji, akcji lub udziałów $)^{16}$.

\section{Podsumowanie}

Strażnicy Straży Marszałkowskiej podlegają m.in. zakazowi podejmowania zajęć zarobkowych, który należy interpretować z uwzględnieniem stanowiska wyrażanego w odniesieniu do podobnych zakazów obowiązujących funkcjonariuszy innych służb zmilitaryzowanych, takich jak np. funkcjonariusze Policji. Zakaz $\mathrm{z}$ art. 45 ust. $1 \mathrm{w}$ związku $\mathrm{z}$ art. 46 ustawy o SM pozwala funkcjonariuszom SM jedynie na podejmowanie zajęć o charakterze naukowym i naukowo-dydaktycznym.

Okazjonalny najem mieszkania przez funkcjonariusza nie jest zajęciem zarobkowym w rozumieniu art. 45 ust. 1 tej ustawy. Jeżeli wynajem byłby prowadzony w ramach działalności gospodarczej, funkcjonariusz podlegałby zakazowi ustalonemu w art. 4 pkt 6 ustawy z 21 sierpnia 1997 r. o ograniczeniu prowadzenia działalności gospodarczej przez osoby pełniące funkcje publiczne.

\section{Bibliografia}

Bielecki L., Ustawa o stużbie cywilnej. Kontrowersje natury prawnej dotyczace pracobiorcy jako źródła rozwiązań prawnych (zagadnienia wybrane), „Przegląd Prawa Publicznego" 2014, nr 7-8.

Cudowski B., Dodatkowe zatrudnienie, Warszawa 2007.

Lipski J., Nalaskowska U., Zeidler K., Ustawa o Biurze Ochrony Rzq̨du. Komentarz, 2008, LEX. Opaliński B., Rogalski M., Szustakiewicz P., Ustawa o Policji. Komentarz, 2015, Legalis.

2. Przełożony może zezwolić funkcjonariuszowi na podejmowanie zajęć zarobkowych poza służbą, jeżeli nie koliduje to $z$ wykonywaniem zadań służbowych przez funkcjonariusza oraz wplywa dodatnio na podwyższenie jego kwalifikacji, a także nie narusza prestiżu stużby.

16 J. Lipski [w:] J. Lipski, U. Nalaskowska, K. Zeidler, Ustawa o Biurze Ochrony Rządu. Komentarz, 2008, LEX. 